\title{
Hijrahtainment: Composing Piety and Profane as Commodification of Religion by Media
}

\author{
${ }^{1}$ Ratri Rizki Kusumalestari \\ Fakultas Ilmu Komunikasi, Universitas Islam Bandung, Jalan Tamansari No.1 Bandung, Indonesia. \\ E-mail: ${ }^{1}$ ratri@unisba.ac.id
}

\begin{abstract}
According to the constructionism paradigm in communication and media theory, social reality is constructed by the media based on its ideology. The media construct various realities in the real world into a second reality. One of them is the rise of artists who explore Islam and decide to "emigrate" or "hijrah." Using the Murray Edelman framing method, this study explores how online media okezone.com, detik.com, and tribunnews.com frame the hijrah phenomenon of Indonesian artists in entertainment packages and bring up the term hijrahtainment. The results of this study show that the media construct two frames, namely the ideal millennial frame and the piety and profane frame. The categorisation from the three online media offers religion commodification in the frame of piety, mixing with profanity like entertainment.
\end{abstract}

Keywords: hijrahtainment, media framing, online media, hijrah, Indonesian artists

\section{INTRODUCTION}

Recently, there has been a phenomenon of artists' hijrah or change to a better attitude that is more Islamic than before. They began to explore the teachings of Islam and change their appearance to be more Islamic. This is related to the increasing permissiveness of the entertainment world to artists with Islamic appearance. Ary Budiyanto, an anthropologist and researcher at the Center for Culture and Frontiers Studies Universitas Brawijaya, said that the phenomenon of the hijrah of artists has existed since the 1990s. The next wave of the hijrah of artists emerged in 2015, along with Salafi recitation's proliferation among Indonesian artists, marked by the emergence of a community called
Musawarah (Muda Sakinah Mawaddah Warahmah) with many artists as its members (Fitri \& Jayanti, 2020).

The media is starting to see a very potential business market and turn various Islamic brands into commodities. This raises the need for commercial stars with Islamic images. Also, the proliferation of broadcasts with Islamic content on television, such as soap operas, infotainment, and reportage on Islam, of course, requires more and more Muslim and Muslimah artists presenting Islamic images. An article published by the online media Suaraislam.co reviewed the hijrah by saying that hijrah was trending. Anything about Islam or has an Islamic brand will sell well. Such as Muslim clothing, Umrah and Hajj trips, Islamic 
books, halal food, Islamic schools, sharia hotels, and halal make-up, many people are also interested (https://www. suaraislam.co/arus-balik-hijrah). The same thing was found in this research on the social media of artists who do hijrah. The results show that the hijrah carried out by the artists is a new type of commodification by making religion something that is traded (Amna, 2019).

In Indonesia, the issue regarding religiosity in the context of socio-cultural and media is one of the issues that has attracted attention. The hijrah of artists is one of these issues. Although it is a personal domain because it is closely related to one's beliefs and choices, the process of hijrah by Indonesian artists is often a commodity for the media. This is because the hijrah movement is now communal and makes young people the object of preaching in their recitation (Addini, 2019). This can be said to be a new phenomenon in understanding the hijrah.

Moreover, the terminology of hijrah has shifted. Initially, hijrah meant the move of Prophet Muhammad SAW from Mecca to Medina to facilitate the spread of Islam teaching. Furthermore, according to Muhammad As'ad, hijrah changes its meaning to become a cultural meaning-individuals who stay away from harmful behavior to obtain a more Islamic lifestyle (Fajriani, 2019). When the artist performs hijrah, the definition of hijrah, which is considered sacred and religious, finds new meaning when it intersects with the world of entertainment, which is considered to be contrary to sacredness.

The study of hijrah widespread with youth or millennials is one of the most famous studies recently. Several studies ranging from research on hijrah adolescents and social media (Syahrin \& Mustika, 2020), search for millennial identity through hijrah (Zahara et al., 2020), the meaning of hijrah for students (Setiawan, 2017), to millennial identity negotiations (Sunesti et al. al., 2018). All the studies show that the trend of hijrah among millennials is on the rise and is no longer in the personal sphere but has turned into a communal movement (Anisa, 2018). A study of the millennial community in the Line chat group (Prasanti \& Indriani, 2019) found that hijrah is interpreted as a life goal to make changes towards better things following Islamic values, hijrah must be demonstrated in both a verbal and nonverbal context by each member of the community, and hijrah is defined as the formation of the identity of each member in the community.

These studies attracted the author to see how the media captured the reality of the hijrah of artists. The fact that the hijrah phenomenon of Indonesian artists is captured by the media in different ways according to the interests and ideology of each media, so the author is interested in exploring this discourse at the micro-level (media text), that is how online media frame the phenomenon of the hijrah of artists in Indonesia.

The role of mass media and its relationship with society is still the concern of many researchers today. In the sociocultural context, the emphasis is more on media content, as stated by McQuail that mass media has a pattern of idealistic relationships with society in the sense that mass media content is assumed to have a significant latent influence. Ideas, values , and images displayed by the media are often considered the main causes of value changes in society (McQuail, 2010). Until now, studies on the construction of mass media reality have been carried out by many communication experts, especially media and cultural studies. However, diverse and ever-changing phenomena and analyzes have kept the study of this field growing. 
A study that focuses on media ideology and religion is Ahmad Muttaqin's research in his writing entitled "Religion in the Ideology of Mass Media Representation." He stated that religion for the mass media is a strategic issue that becomes an instrument for mobilizing readers. The way this is done is through the production and reproduction of ideological values based on religious understanding. In the Indonesian context, the understanding of religion is built into several insights or mainstreams, generally divided into 3 (three) main spectrums: fundamentalists, modernists, and liberals (Muttaqin, 2012).

This symbolization process will economically provide capital benefits for the mass media by ensuring the market (readers) of groups and communities related to certain ideologies (Muttaqin, 2012). In the context of the hijrah of artists, there are two different ideological directions. These are hijrah that is oriented towards sacred things and even tends to an extreme to radical understanding. On the opposite, hijrah is associated with things that are profane or worldly, such as Islamic fashion, Islamic culinary delights, Islamic tourism, Islamic social media content, as well as the earthly life of artists.

According to Stig Hjarvard, as quoted by Iswandi Syahputra, the main point of the study of media relations and religion sets on how the meaning of something sacred like religion produced by the media as something profane? The study of religion and media relations can appear in two traditions (Hjarvard, 2008). First, religion in the media, which examines how religion and important religious texts represented in the media and their influence on individuals and institutions in a broader context. Second, media as religion combines a more general understanding of religion as a cultural meaning-making practice. As with other religious issues, the meaning of the hijrah of artists by the media is represented in the media's coverage in different frames.

The results of Iswandi Syahputra's research show that religious commodities are used as a strategy to broaden audience coverage. The relation between these various conditions can lead to a new situation of mass culture and symbolic religiosity. Religionturned into aspectacle, not guidance. In practice, the presence of religion in social life is sufficiently practiced by consuming various religious symbols. This condition shows the loss of religious spirituality. Religion without spirituality will only leave rituals (Syahputra, 2016). The reality of the hijrah of artists in online media indicates something that more or less resembles this symbolic religiosity. Inspired by the term dakwahtainment, which is used to describe the commodification of da'wah (Alansori \& Zahidi, 2019), the author sees the hijrahtainment phenomenon that is starting to emerge as a new discourse.

Lukas S. Ispandriamo's research shows that in Indonesia, religious coverage generally represents some trends. First, religious coverage is generally still centered on ritual activities and religious celebrations, religious institutions, and especially incidents of violent conflict. Second, because it tends to focus on conflict events, religious coverage is usually very sensational and full of dramatization. Third, the media still often label certain religious groups or sects. Fourth, the media also less often give a place to minority groups. If anything, it is an exclusive minority group that tends to spread hatred, violence, and other actions that attract media attention because they are often considered to have news value (Ispandriamo, 2016). The coverage of the artists' hijrah in mass media also moves in the four realms mentioned above, either directly or indirectly.

In this article, the author uses a 
constructivist paradigm that views social reality as a construction, not something natural. Constructionists emphasize their analysis of how reality is constructed or formed. In the context of media studies, the constructivist approach looks at how messages or texts are produced and reproduced. McQuail (2010: 111) provides propositions related to this view that society is a constructed reality, media is a provider of material for the production of reality, the meaning is what offered by the media but can be negotiated or even rejected, media selectively reproduces specific meanings, and all facts are the result of interpretation. Therefore, it is clear that the media framing of reality in its production process represents reality according to the media ideology.

According to Eriyanto, the maker of texts representing reality goes through 3 (three) processes (Eriyanto, 2012). First, encoded events, such as events faced by journalists to be presented to the public through mass media, are constructed with the help of signs, such as photographs, pictures, or graphics. Second, the depiction of reality, namely the use of certain words or sentences that carry specific meanings when accepted by the public. Third, the arrangement of the events of the object of representation in ideologically acceptable conventions. The difference in the ideology that journalists have will affect the representation displayed and cause differences in the reality frame by the media. According to Todd Gitlin, quoted by Eriyanto, framing is a strategy of how reality or the world is formed and simplified in a way to be presented to the public. The frame is the principle of selection, emphasis, and presentation of reality. This has attracted the attention of researchers to explore how media constructs the reality of artists who emigrate related to the ideological map of Indonesian society. This study seeks to capture the framing of discourse on the artist's migration by the media, especially by online media in Indonesia.

\section{METHOD}

The author uses qualitative methods to reveal further findings regarding the media's framing as the object of this study. The analytical tool, as well as the approach used, is Murray Edelman's framing analysis. Framing analysis is an analysis used to see how the media construct reality. This analysis is also used to see how events are understood and framed by the media (Eriyanto, 2002). There are two main framing essences, namely how events are interpreted and how written facts. For this research, Edelman's framing approach adapted and adjusted to see representations and ideology in the media, particularly those related to the phenomenon of the hijrah of Indonesian artists.

The same reality will produce another different reality when framed or constructed in different ways. The reality that is understood by the audience is a reality that is selected. The audience is dictated to understand reality in a certain way or with a specific frame depending on the media that construct it. In Edelman's view, framing is categorization or the perspective that uses certain words that indicate how facts or reality are understood. The use of specific categories of reality is more subtle and closer to the subconscious. It means that the audience is not aware that their thoughts and awareness have been led to a certain point of view or perspective, even specific patterns of thinking.

Edelman's important concept regarding categorization is rubrication. It is how an event in the news is categorized in specific rubrics regarding how facts are classified into certain categories. In this study, the news texts as the study's subject were analyzed based on their categorization and rubrication to see what 
frames were used by the media.

The data collection used in this study is technique documentation. The technique is a data collection technique done by studying existing documents so that it can be used in the research, obtained, and complemented required data. Besides, researchers also use observation techniques. Observation in this context means that after the data is collected, the researcher does observation (Sugiyono, 2010).

This study uses a purposive sampling technique with specific subject requirements. The subject in this study was the news about the hijrah of artists from 2018 to 2019. The purpose of determining the period of the study was to limit the focus of this research. The author selects five news for each media based on the criteria for news topics related to the artist's hijrah and takes just one story with similar topics. The media chosen are online media that are in the top three rankings according to the Alexa rating in December 2019, there are okezone.com, detik.com, and tribunnews.com. The list of news researched and analyzed in this study is in the TABLE 1.

Qualitative data analysis is an effort made by working with data, organizing data, sorting it into units that data will be able to be managed, synthesizing, looking for and finding patterns, finding what is essential and learned, and deciding what to share with others (Lexy J. Moleong, 2000). The findings were analyzed using the Edelman framing framework according to their categorization and rubrication and associated with similar studies.

\section{RESULT}

The reality of the hijrah of artists and the religious movement among the artists is nothing new. But lately, the hijrah of artists has been mostly carried out through the community. This form has moved artists to hijrah, become increasingly prevalent, more and more millennial young artists have decided to start exploring Islam, leaving behavior that can lead to ugliness and changing lifestyles by getting closer to religious matters. It is inseparable from the media's role in raising this issue to be one of the exciting topics in its content.

\section{Rubrication: Hijrahtainment}

Different media placed this situation in different frames. This is the initial stepping stone for the author to explore further the phenomenon regarding the hijrah of Indonesian artists that captured by the media. According to Murray Edelman's point of view, the author describes the research findings by observing media coverage through categorization, especially rubrics. How do online media such as okezone.com, detikhot, and tribunnews.com choose the words in their writings, and how the three media incorporate the topic on hijrah of artists into the existing rubric.

Rubrication is the aspect of categorization that shows clearly how the media places an issue in their frame. Based on the results of the study of media texts by the author, it shows that the three media perform almost the same rubrics as shown in the TABLE 2.

The hot gossip rubric at okezone. com.com mostly contains stories of celebrities and other figures close to the entertainment world; sometimes, even the news is controversial. Likewise, the detikhot.com and wolipop rubrics have raised issues of celebrities and controversies in the entertainment world. Like the two previous media, the celebrity at tribunnews.com.com rubric also contains news about the world of entertainment that is synonymous with fun and other profane pleasures.

These three online media in Indonesia classify media texts about 
Ratri Rizki Kusumalestari. Hijrahtainment: Composing Piety and Profane...

TABLE 1. News on Artists` Hijrah in Indonesian Online Media

\begin{tabular}{|c|c|c|}
\hline MEDIA & EDISI & JUDUL BERITA \\
\hline \multirow[t]{5}{*}{$\begin{array}{l}\text { okezone. } \\
\text { com.com }\end{array}$} & $\begin{array}{l}\text { Saturday, } \\
\text { 27/01/2018 } \\
\text { 17:04 WIB }\end{array}$ & $\begin{array}{l}\text { Ramai Artis Hijrah, dari Orang Terdekat hingga Sosok Tak } \\
\text { Dikenal Jadi Sumber Hidayah } \\
\text { https://celebrity.okezone.com.com/ } \\
\text { read/2018/01/27/33/1851086/ramai-artis-hijrah-dari-orang-ter- } \\
\text { dekat-hingga-sosok-tak-dikenal-jadi-sumber-hidayah }\end{array}$ \\
\hline & $\begin{array}{l}\text { Friday, } \\
03 / 05 / 2019 \\
12: 12 \text { WIB }\end{array}$ & $\begin{array}{l}\text { Pernah Hijrah, } 5 \text { Artis Ini Putuskan Lepas Hijab } \\
\text { https://muslim.okezone.com.com/ } \\
\text { read/2019/05/03/617/2051008/pernah-hijrah-5-artis-ini-putus- } \\
\text { kan-lepas-hijab }\end{array}$ \\
\hline & $\begin{array}{l}\text { Thursday, } \\
02 / 05 / 2019 \\
16: 59 \text { WIB }\end{array}$ & $\begin{array}{l}\text { Cerita di Balik Hijrahnya } 5 \text { Artis Tanah Air } \\
\text { https://muslim.okezone.com.com/ } \\
\text { read/2019/05/02/614/2050683/cerita-di-balik-hijrahnya-5-ar- } \\
\text { tis-tanah-air }\end{array}$ \\
\hline & $\begin{array}{l}\text { Monday, } \\
\text { 09/09/2019 } \\
14: 40 \text { WIB }\end{array}$ & $\begin{array}{l}\text { Irish Bella Mantap Berhijab, Ammar Zoni Buktikan Dukungan } \\
\text { https://celebrity.okezone.com.com/ } \\
\text { read/2019/09/09/33/2102461/irish-bella-mantap-berhijab-am- } \\
\text { mar-zoni-buktikan-dukungan }\end{array}$ \\
\hline & $\begin{array}{l}\text { Tuesday, } \\
\text { 19/11/2019 } \\
\text { 01:06 WIB }\end{array}$ & $\begin{array}{l}\text { Komunitas Hijrah Gampang Bilang Orang Masuk Neraka, } \\
\text { Ustadz Das'ad Latif: Kau Panitia Hari Kiamat? } \\
\text { https://muslim.okezone.com.com/ } \\
\text { read/2019/11/19/614/2131514/komunitas-hijrah-gampang-bil- } \\
\text { ang-orang-masuk-neraka-ustadz-das-ad-latif-kau-panitia-hari- } \\
\text { kiamat }\end{array}$ \\
\hline \multirow[t]{5}{*}{$\begin{array}{l}\text { detik. } \\
\text { com }\end{array}$} & $\begin{array}{l}\text { Monday, } \\
18 / 02 / 2019 \\
15: 03 \text { WIB }\end{array}$ & $\begin{array}{l}9 \text { Pasangan Artis yang Kompak Berhijrah, Makin Harmonis } \\
\text { https://wolipop.detik.com/foto-hijab/d-4433242/9-pasangan- } \\
\text { artis-yang-kompak-berhijrah-makin-harmonis }\end{array}$ \\
\hline & $\begin{array}{l}\text { Monday, } \\
13 / 05 / 2019 \\
12: 50 \text { WIB }\end{array}$ & $\begin{array}{l}\text { Dear Artis, Ustaz Wijayanto Sebut Hijrah Bukan Cuma Atribut } \\
\text { tapi Juga Attitude } \\
\text { https://hot.detik.com/celeb/d-4547106/dear-artis-ustaz-wi- } \\
\text { jayanto-sebut-hijrah-bukan-cuma-atribut-tapi-juga-attitude }\end{array}$ \\
\hline & $\begin{array}{l}\text { Tuesday, } \\
\text { 28/05/2019 } \\
21: 41 \text { WIB }\end{array}$ & $\begin{array}{l}\text { Hijrah Tanpa Pendampingan Bisa Jadi Jalan Masuk Radika- } \\
\text { lisme } \\
\text { https://news.detik.com/berita-jawa-timur/d-4568936/pen- } \\
\text { gamat-hijrah-tanpa-pendampingan-bisa-jadi-jalan-masuk-radi- } \\
\text { kalisme }\end{array}$ \\
\hline & $\begin{array}{l}\text { Friday, } \\
14 / 06 / 2019 \\
16: 30 \text { WIB }\end{array}$ & $\begin{array}{l}\text { Belajar Hijrah, Jhody sampai Ditegur Istri dan Hilang Peker- } \\
\text { jaan } \\
\text { https://hot.detik.com/celeb/d-4586470/belajar-hi- } \\
\text { jrah-jhody-sampai-ditegur-istri-dan-hilang-pekerjaan }\end{array}$ \\
\hline & $\begin{array}{l}\text { Tuesday, } \\
17 / 12 / 2019 \\
14: 50 \mathrm{WIB}\end{array}$ & $\begin{array}{l}10 \text { Selebriti yang Putuskan Berhijab di 2019, Mantap Hijrah } \\
\text { https://wolipop.detik.com/foto-hijab/d-4826074/10-selebri- } \\
\text { ti-yang-putuskan-berhijab-di-2019-mantap-hijrah }\end{array}$ \\
\hline
\end{tabular}


Tri- $\quad$ Sunday, Bersyukur Shireen Sungkar Sudah Menutup Aurat, Teuku bun-news 27/05/2018 Wisnu Ogah Paksa Istrinya Pakai Cadar

03:44 WIB https://www.tribunnews.com.com/seleb/2018/05/27/ bersyukur-shireen-sungkar-sudah-menutup-aurat-teuku-wisnu-ogah-paksa-istrinya-pakai-cadar

Sunday, Dimas Seto Beri Kebebasan Dhini Aminarti Jika Ingin Me27/05/2018 makai Cadar

03.37 WIB https://www.tribunnews.com.com/seleb/2018/05/27/dimas-se-

Tuesday, Kisah Hijrah Dari Dunia Metal ke Religi, Ustaz Derry Sulaim16/04/2019 an: Boleh Rock n Roll Tapi Jangan Molor 10:38 WIB https://www.tribunnews.com.com/seleb/2019/04/16/kisah-hijrah-dari-dunia-metal-ke-religi-ustaz-derry-sulaiman-bolehrock-n-roll-tapi-jangan-molor

Thursday, Sejumlah Artis Ini Hijrah, Arie Untung Ungkap Alasannya 05/09/2019 Sebenarnya Kumpul-kumpul Artis undang Ustadz

10:37 WIB https://tribunnews.com.com/2019/09/05/sejumlah-artis-ini-hijrah-arie-untung-ungkap-alasannya-sebenarnya-kumpul-kumpul-artis-undang-ustaz

Monday, Revalina S Temat Curhat Proses Hijrahnya hingga Kenakan 28/10/2019 Hijab: Suamiku Awalnya Ngeremehin Aku Gitu

19:47 WIB https://www.tribunnews.com.com/seleb/2019/10/28/revalina-s-temat-curhat-proses-hijrahnya-hingga-kenakan-hijab-suamiku-awalnya-ngeremehin-aku-gitu

the hijrah of artists in the entertainment section and not in the religious news rubric that should be closely attached to the word hijrah used. This shows that the media are trying to shift the terminology of hijrah that is considered sacred, to be closer to worldliness. This shift gave rise to a new understanding of hijrah, which began to enter the entertainment world that could be represented by the terminology of hijrahtainment.

\section{Ideal Millennial Frame}

The first frame that is visible in the media capture is the formation of a new image of the embodiment of the millennial ideal that has physical, material, and religious advantages that are not left behind. This depiction frames the hijrah artist's reality in the description of a harmonious young family, an understanding husband, and a wife who is obedient to her husband as taught in Islam. Quotations from the statements of artists such as Irish Bella - Amar Zoni, Teuku Wisnu - Shireen Sungkar, and Dimas Seto - Dini Aminarti to build this frame quite strongly. This framing is

TABLE 2. Rubrication of Media on Hijrah of Indonesian Artists

\begin{tabular}{ll}
\hline \multicolumn{1}{c}{ MEDIA } & \multicolumn{1}{c}{ RUBRIC } \\
\hline okezone.com & hot gossip, serba serbi okezone.com \\
detik.com & detikhot dan wolipop \\
tribunnews.com & tribunnews.com seleb \\
\hline
\end{tabular}


visible in the following uploads:

"One of the hijrahs that have not carried out is wearing the hijab. Moreover, my wish from before marriage to wear the hijab received support from my husband," said Irish Bella ... Apart from supporting his wife, praise was also said by Ammar Zoni to his wife. "Seriously, I don't feel that you are beautiful. Netizens throughout Indonesia, can you see she's really pretty, right?" he said. (okezone.com.com) "It's up to Shireen (for the veil)," said Teuku Wisnu when he was met in the Blok S area of South Jakarta, Saturday (26/5/2018). He is grateful that now Shireen covered her body and wearing a hijab. "That depends on Shireen's choice. He's already covered his corpus. But for the case (wearing veil), it's up to Shireen," he added. (tribunnews.com.com) "Free, Masya Allah, if you want that (veil), it must be appreciated well," said Dimas Seto ... He said he was responsible for his wife. Including being responsible for the wife to cover her genitals. "Living as a Muslim closes your genitals. If I am the responsibility of my wife," said Dimas. (tribunnews.com)

In contrast to tribunnews.com.com and okezone.com.com, detik.com.com formed this ideal millennial frame in the media text in the form of a photo gallery of artist couples entitled "9 Artist Couples who are Compact Migrating, More Harmonious". The captions in each photo frame these artist couples as harmonious couples, love each other, and live a closer life to His Creator, Allah SWT. FIGURE 1 is the photos and their captions.

This framing constructs the reality of the ideal husband and wife figure in a household, especially couples that have decided to hijrah and implement it in their daily lives. The fact that they are young, beautiful, handsome, and wealthy artists is a predicate attached to them as celebrities. It strengthens their image as ideal millennials who have a balance in life, that is profane and religious.

Several conducted studies have also shown similar findings regarding the identity of millennials who decide to migrate. They want to become better human beings and make religion (Islam) a reference for their behavior. This also cannot be separated from the existence of recitation of young clerics such as Hanan Attaki, which packs the issue of love that is close to youth and millennials with religious advice. The artists who hijrah became a reference group for them.

\section{Piety and profane frame}

Hijrahtainment has changed the definition of a sacred and religious hijrah into more profane. Hijrah, which is considered possible to do by people who understand religion or have qualified religious knowledge, has now turned into a more earth-stepping terminology. Hijrah is also closer to millennials who think that they are just starting to study Islam. Besides, some online media uploads imply that the hijrah can be done by anyone, even if someone has done things that violate religion to a considerable extent. This can be seen from the interview excerpt regarding the process of moving the artists in the following uploads:

"The story of the artist's and the public's life journey is always interesting to notice, especially the spiritual experiences they have experienced. We certainly still remember the figure of the late Ustad Jefri Al Buchori or Uje? ... Even though it looks perfect, it's no secret that Uje's past is full of 


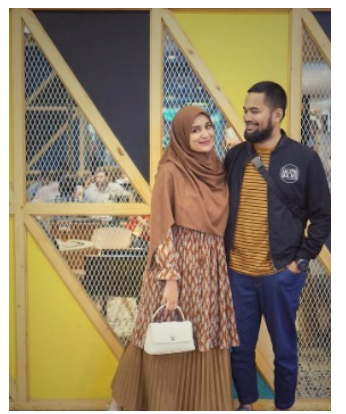

Teuku Wisnu is in the ranks of artists who echo the phenomenon of hijrah. His wife, Shireen Sungkar, also changes her clothes to syar' $i$ and regularly participates in recitation with her husband.

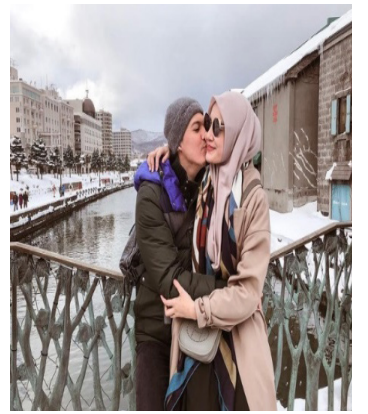

Following his younger sister, Zaskia Sungkar and Irwansyah also hijrah.

They both changed their appearance and lifestyle to conduct recitation regularly.

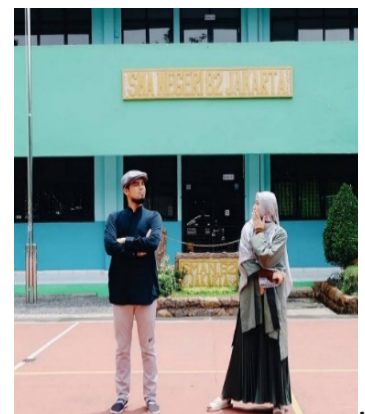

Other figures who change their lifestyle according to sharia are actor Mario Irwinsyah and former presenter Ratu Anandita. This harmonious couple also continues to preach in various ways.

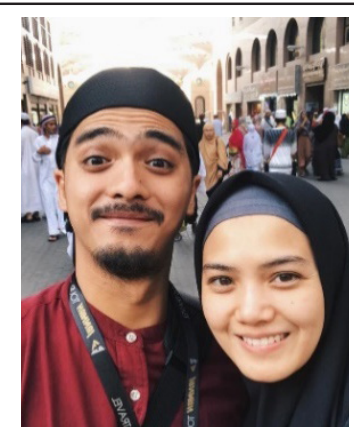

The artist couple Herfiza and Ricky Harun also decided to hijrah. They regularly attend recitation, and the wife Herfiza also wears a syar'i outfit.

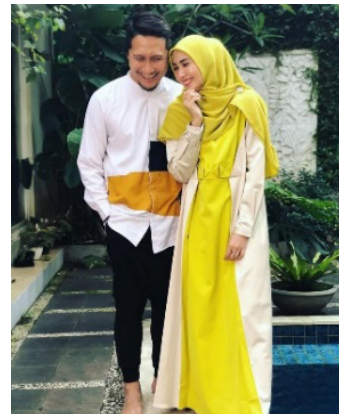

Recently participated in recitation, Arie Untung finally asks his wife Fenita Arie to get closer to Allah SWT. Fenita decided to wear a hijab and left the entertainment in 2018.

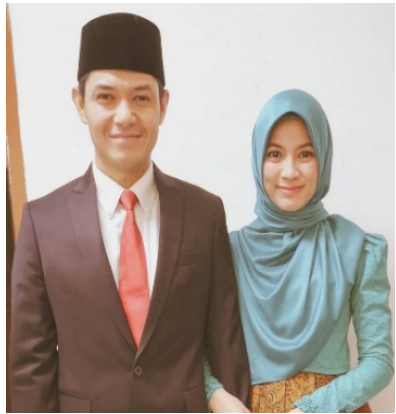

Dude Harlino and Alyssa Soebandono also decided to hijrah. They and several other artists formed a forum named 'Mewah' that means Menjalin Ukhuwah.

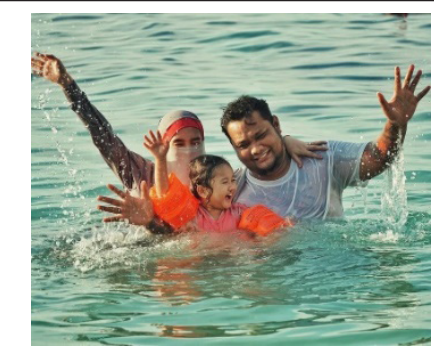

The vocalist 'Last Child', Virgoun has also changed his lifestyle to be more Islamic. In fact, his wife Inara is now sure to wear a veil in her daily life.

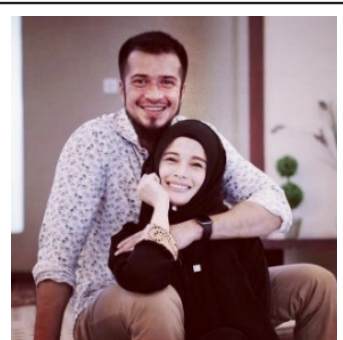

Although rarely seen on social media, Primus Yustisio and Jihan Fahira are seen frequently following the study. They also send their children to Islamic boarding schools to build a family close to Allah SWT

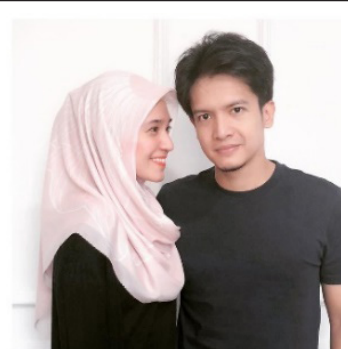

The soap opera star couple Dimas Seto and Dhini Aminarti also decided to hijrah. Even so, they are still active in acting but also regularly participate in recitation.

FIGURE 1. Artists couple who decided to hijrah 
Ratri Rizki Kusumalestari. Hijrahtainment: Composing Piety and Profane...

darkness. "(tribunnews.com)

The media frame shows that the reason for hijrah does not have to be contemplation and long religious experience. It makes the hijrah as easy for anyone to do. The media took part in framing this issue. The three media's uploads in this study show how the hijrah process can be experienced by anyone and in various ways. Some have to pass through obstacles, but some pass smoothly without significant barriers. This presented by the media in the following news text:

"Fenita Arie also experienced an unpleasant incident, when hot water from the teapot spilled over her thighs when she wanted to make coffee for her husband ... She also felt that this was a warning from Allah, Fenita said that even hot water in the world is like that. Especially hot in the afterlife. This incident finally solidified her to hijrah." (okezone.com)

"Actress Nyimas Khodidjah Nasthiti Adinda or known as Dinda Hauw, first uploaded her photo wearing a hijab on March 25, 2019. The movie star for Surat Kecil untuk Tuhan, was wearing a hijab after dreaming of falling from a plane." (detik.com)

On the other hand, the media do not want to simplify the meaning of hijrah and make it something that can be done carelessly. The media also took the case of artists who experienced unpleasant things when they started their hijrah. This can be seen from the news uploaded by the media citing the statement of the artist who had a long hijrah process as follows:

"I felt empty even though I had a lot of money and was popular as a band member. Happiness turns out to be a matter of worship obedience, not wealth or popularity, "he said. Due to his intense study of religion, Ustadz Derry Sulaiman" skipped "and did not perform with Betrayer. From mid-2000 to 2011, he did not hear music at all." (tribunnews. com)

"In the process of hijrah, it is clear that nothing is made easy by Allah. It must be full of trials. The toughest trial in the family was because it was honest at that time because of the approach to God, again at the same time as God, to be honest, so it ignored living, " Jhody admitted. (okezone.com)

Another important theme in media framing regarding the hijrah of artists is the scholars' opinion in Islam. The issue of hijrah is in the realm of Islam, so the ulama or ustad are the ones who have to give their idea. It is incomplete if the media presents the reality of the hijrah without using the ustad or ulama as the informant. The opinions of religious experts are framed as wise advice and a warning to millennial youth that hijrah is not something that can be viewed easily. The frame formed by the media related to the ulama's view of the hijrah of artists is a criticism of the behavior of some migrant communities who easily disbelieve other people and feel they know everything about hell as if they are the committee of doomsday. This is seen in the following upload:

"These are children whose communities hijrah, it is easy to disbelieve people ... It is as if they are the doomsday committee because they feel they know everything about reward and sin. "Understanding religion is only half-hearted; everyone is 
interpreted. (Everyone) In contrast to the manhaj it is said to be wrong, heresy, go to hell. Heh! You are the doomsday committee? It's strange, kids nowadays, it's really easy (to judge)," added Ustadz Da'sad Latif humorously." (okezone.com)

Okezone.com.com uploaded a quote from Ustad Da'sad Latief's advice about his criticism of young people's behavior or millennial migrants who infidel people. It shows the legal perspective on the reality of hijrah, namely criticizing the attitude of those who sometimes consider themselves the most correct. The tone of the sentence which is used as a harsh title, although it is said with a humorous tone, is not written in the title, that is "Komunitas Hijrah Gampang Bilang Orang Masuk Neraka, Ustadz Das'ad Latif: Kau Panitia Hari Kiamat?" ("The Hijrah Community is Easy to Say People Go to Hell, Ustadz Das'ad Latif: You are the Committee or the Day of Judgment?")

Meanwhile, detik.com.com views the reality of this hijrah with a more moderate categorization with the title "Hijrah Tanpa Pendampingan Bisa Jadi Jalan Masuk Radikalisme" ("Hijrah Without Assistance Can Be a Way of Entry to Radicalism"). Radicalism has prevented this by hijrah, especially the hijrah community. However, detik.com did not make a controversial title when framing this reality. The emphasis lies in the message that apart from being not easy, hijrah can be a way of entering terrorism without assistance because hijrah is one of the radicalism components that leads to terrorism. There are many things to watch out for, as seen in the following upload:

"Yes, that is the way to enter terrorism. Because there were faith, hijrah, and jihad. So if they do not get good assistance in the area (when) they hijrah, they will slightly enter their version of jihad. For example, there are already many artists at this time, " said Akhmad Muzzaki, a radicalism movement observer. (detik.com)

Another post entitled "Dear Artist, Ustaz Wijayanto Called Hijrah Not Only Attributes but Also Attitude." The choice of words in this title seems wiser and less judgmental. This is advice reminding that hijrah is not just a symbol but must be applied in daily behavior, as in the following upload:

"But what should be noted is not only the attributes must be attitude, attitude, behavior, actions, everything is not only physical changes, mental changes," he remembered. "It is not just a symbol, but there are values. The values start from the physical, mental, and heart values, all actions must be disregarded ..."(detik.com)

The tone in the two titles used by detik.com seems different from the titles used by okezone.com.com. The words in the title indicate the position of detik.com in the discourse on this hijrah of artists. Explicitly, the formed reality is the same, in the framework of the ulama's advice, but with a different tone. This is also seen in the following okezone.com.com uploads:

Not a few Indonesian artists initially decided to cover their bodies with their hijabs but suddenly failed in the middle of the road. They deliberately took off their hijab for various reasons. They immediately looked sexy and seductive to anyone who saw them. They were not ashamed of their nakedness, even though they had time to cover it with polite clothes. (okezone.com)

Although not quoting the ulama's opinion, uploading the okezone.com. 
com this time is like giving an implicit warning that it is not easy to hijrah. The story of several artists who have decided to hijrah and take off their hijab, the okezone.com.com has chosen to be given the title "Pernah Hijrah, 5 Artis Ini Putuskan Lepas Hijab" ("Ever Hijrah, These 5 Artists Decided to Leave Hijab") with the hashtag failed to hijrah. The entertainment world is indeed not an easy place for artists who have not strong faith, that is the message conveyed through this upload. Regardless of the background of these artists' failure, okezone.com.com put it in a clear judgement frame.

The construction of reality carried out by the three media towards the phenomenon of the artist who does hijrah shows that in general, all of them put the elements of piety or sacredness and profane or worldliness in the same frame.

\section{DISCUSSION}

On the construction of this hijrah phenomenon, the categorization is chosen by tribunnews.com.com, detik.com, and okezone.com.com still tends to be the same. Hijrahtainment as a rubrication remains the scope in selecting essential themes and the use of words by the three media. At the micro or text level, hijrahtainment has changed the meaning of the word hijrah. If examined further at the macro or socio-cultural level, this hijrahtainment is very interesting considering its ability to shift the meaning of the word hijrah, which is sacred and related to piety and heavenly matters, into a term that is close to the entertainment and is identical to profane.

\section{Hijrahtainment in a Media Frame: The} Politics of Commodification of Religion

The framing cannot be separated from construction, ideology, and of course, media politics. In Edelman's view, the choice of words used by the media shows how reality is captured, understood, and recreated by the media. The discourse of the hijrah of artists framed by the media is undoubtedly not without purpose. Why do online media in Indonesia construct the reality of the hijrah of artists in the frames as described in the research finding?

In a constructivist framework, the media do not produce news in a valuefree manner. This means that the media have an interest in the discourse being conveyed. Why do the media raise the ideal millennial frame? It is because Muslim millennials are the potential market for media, and they are the digital native generation who consume more information from cyberspace. According to several studies, religiosity is one of the values that develop among millennials. If we look from the media industry's perspective, there is no denying the fact that the media in Indonesia seek to profit by selling programs, rubrics, news, or whatever products they produce.

Noor (2016) said that religious behaviour and norms - which include dress, symbols, rites, and rituals but not the essential core of the religious practice itself, namely faith - have all been rendered commodities in a world that is already saturated by over-determined identitymarkers. Commodification, in the view of the media industry and economics, refers to the process of changing use values into exchange values. It means that something that was previously considered unsold, and then becomes something that can bring profit to the institution or company that uses it.

The first frame, formed by the three online media in this study, shows how the media draws religion closer to the millennial market by presenting the ideal millennial form in the form of migrating artists. They were described as being almost perfect when they can lead a worldly life and a religious balance. The ideal millennial portrait framed by 
the media provides a reference group representation for millennials. Moreover, the hijrah movement is currently booming among millennials, and they need lots of references to do hijrah.

The media construction of the hijrah artists' reality within the ideal millennial frame has shifted the meaning of hijrah into a more popular form, not just merely religious. When hijrah is interpreted as a form of commodification, there are many consumptive things attached to it. The references sought by the public are not only the law of hijrah and hijrah behavior that is following the guidance of Islam, but also fashion, clothing fashions, halal cosmetics, and things related to lifestyle. Indirectly, this provides benefits for other parties who also see the millennial market's potential, such as advertisers and producers of goods and services.

The commodification of religion by media shows the existence of inputs, processes, and outputs, and the production of goods and services. The input is the phenomenon of the hijrah of Indonesian artists. The process is producing messages carried out by the media, starting from finding data and facts, processing them into news or articles, and presenting them in their interface. In short, the production process is the framing of the media. Meanwhile, the output results from media coverage in the form of news or articles in online media. So, the commodification of religion is the commercialization of religion or converting faith and its symbols into commodities that can trade for profit.

Meanwhile, another frame constructed by the three media has given rise to the meaning of the term hijrah that has become more grounded and closer to people who feel that they are not close to piety matters. According to George Gerbner's thoughts on cultivation (Gerbner, 2007), what this online media does has the same effect as what television did. The media have popularized a discourse that was previously considered unusual, even sacred. Hijrahtainment places hijrah discourse as something that is commonplace and can be done by anyone, and hijrah even tends to be popular. Hijrah, which is often associated with radicalism, terrorism, and distraction, has shifted its meaning to becoming populist when juxtaposed with the world of artists. In constructivist studies, it can be said that the media tries to persuade the audience to interpret the reality of the hijrah of artists as a human thing.

Furthermore, referring to Stuart Hall's view on the work of journalists in making news, the construction of meaning from the discourse on the hijrah of artists involves selecting sources (Helen Davis, 2004). Reporters may not include their opinions in the news, but they can borrow or use resource persons' opinions to convey their ideas or opinions. In the context of the discourse on the artist's hijrah, apart from interviewing artists who have already done hijrah, journalists also choose ustad or ulama as their source. When these media select certain ulama and quote their statements, and then this is part of the media framing.

In addition to supporting the media point of view, the ulama's statement also reflects the ideology of online media that is the subject of this research. Media cited the statement of ulama as religious experts for a reliable reference for their words. It is a counterweight to the reality of the artist's migration framed by the media. This method is also an attempt by the media to keep covering both sides to present balanced information. Based on the mass communication paradigm, there is a shift in the characteristics of the mass media and target audiences in line with changes in a country or nation in an internal order that Muslims need to anticipate, including in preaching (Rachmiatie, 2002). 
Meanwhile, hen publishing articles about artists who failed to migrate, the media named several artists and broadcast their picture, but did not provide balanced news explaining why they returned to opening the hijab after wearing it. What is the reason of wearing hijab? Theological, psychological, or fashionable like suggested by Ahmadi and Yohana (2005). It shows that doing hijrah is not easy.

This hijrahtainment adds to the findings of research on the commodification of religion that has carried out previously that found there was the commodification of religion in various forms, such as Islamic television drama in Indonesia or sinetron religi (Rakhmani, 2016), hijrah of artists as the commodification of religion (Amna, 2019), and Islamisation in the Indonesian media spaces (Osman, 2018).

\section{CONCLUSION}

The commodification of religion carried out by the media can be seen from the framing made by tribunnews. com, detik.com, and okezone.com. The media frames found in this study by categorization were the ideal millennial frame and the piety and profane frame. The two of them show the media's position in viewing the discourse on the hijrah of artists. Media has made religion as commodities to profit from the consumer through this framing mechanism that composes piety and profane in the same frame.

The life of an artist, close to worldly things, hedonism, sometimes even identified with immorality, has now begun to change its meaning. This is inseparable from the media frame regarding the discourse of the hijrah of artists into hijrahtainment rubrics. The media can be said to have succeeded in creating a new reality that can influence the public's thinking on the terminology of hijrah. Hijrahtainment is the novelty produced in this study. The term hijrahtainment arises from combining the terms hijrah and entertainment framed by the media in the same news and article frame.

This study does not compare the three media frames but finds what the media make frames regarding the discourse of the hijrah of millennial artists. The results of this study provide opportunities for further research in a different domain and a broader scope that includes meso and macro levels, not just micro-level. It also gives research choices using many other methods, such as audience ethnography, critical discourse analysis, narrative, or case study.

\section{REFERENCES}

Addini, A. (2019). Fenomena Gerakan Hijrah di Kalangan Pemuda Muslim Sebagai Mode Sosial. Journal of Islamic Civilization, 1(2), 109-118. https://doi. org/10.33086/jic.v1i2.1313

Ahmadi, Dadi \& Yohana (2005). Konstruksi Jilbab sebagai Simbol Keislaman. https://doi.org/10.29313/mediator. v8i2.1155

Alansori, M. Z., \& Zahidi, S. (2019). Dakwahtaiment Televisi Lokal (Tinjauan Kritis Atas Komesialisasi Dakwah JTV Surabaya). Journal of Islamic Civilization, 1(2), 70-82. https://doi. org/10.33086/jic.v1i2.1341

Amna, A. (2019). Hijrah Artis Sebagai Komodifikasi Agama. Jurnal Sosiologi Reflektif, 13(2), 331. https://doi. org/10.14421/jsr.v13i12.1531

Anisa, F. (2018). Hijrah Milenial: Antara Kesalehan dan Populism. Maarif, Vol.13(No. 2), 38-54. https://scholar.google.co.id/scholar?hl=id\&as s d t $=0 \% 2$ C $5 \& \mathrm{q}=\mathrm{tr}$ e $\mathrm{n}+\mathrm{b}$ er hijrah+di+kalanga++milen i a $1 \&$ b t n $\mathrm{G}=\# \mathrm{~d}=\mathrm{g} \mathrm{s}$ qabs\&u=\%23p\%3DTtbLVM96luMJ

Eriyanto. (2012). Analisis Framing: Konstruksi, Ideologi dan Politik Media. LKiS.

Fitri, R. N., \& Jayanti, I. R. (2020). Fenomena Seleb Hijrah: Tendensi Ekslusivisme dan Kemunculan Kelompok Sosial 
Baru. MUHARRIK: Jurnal Dakwah Dan Sosial, 3(01), 1-17. https://doi. org/10.37680/muharrik.v3i01.222

Gerbner, G. \& L. G. (2007). Living with Television: The Dynamics of the $\mathrm{Cu}$ Itivation Process. https://www. semanticscholar.org/paper/Living-with-Television-\%3A-The-Dynamics-of-the-Cu-Gerbner Gross/ d 376313 a cb 16 fc fa 8160434 a c01a23a8e44cb2dc?p2df

Helen Davis. (2004). The Politics of Representation. In Understanding Stuart Hall. Sage Publications Ltd.

Hjarvard, S. (2008). The mediatization of religion: A theory of the media as agents of religious change. Northern Lights: Film and Media Studies Yearbook, 6(1), 9-26. https://doi.org/10.1386/ nl.6.1.9_1

Ispandriamo, L. S. (2016). Agama Dan Media: Pemaknaan Isu Agama Di 'Detiknews.' Millah, XII(2), 595-616. https://doi.org/10.20885/millah.volxii. iss 2 . art13

Lexy J. Moleong. (2000). Metodologi Penelitian Kualitatif. PT. Remaja Rosdakarya.

Mas'udi. (2017). (Menggagas Prinsip-prinsip Etis dalam Jurnalistik). 211-231. http:// journal.stainkudus.ac.id/index.php/komunikasi/article/download/434/459

McQuail, D. (2010). Teori Komunikasi Massa (Edisi 6). Salemba HUmanika.

Muttaqin, A. (2012). Agama Dalam Representasi Ideologi Media Massa. KOMUNIKA: Jurnal Dakwah Dan Komunikasi, 6(2). https://doi.org/10.24090/ komunika.v6i2.349

Osman, N. A. \& M. N. M. (2018). Islamisation in the Indonesian media spaces new sites for a conservative pushNo Title. LJournal of Religious and Political Practice, Volume 4(Islamisation in Southeast Asia: Religion, Politics and Beyond).

Prasanti, D., \& Indriani, S. S. (2019). Konstruksi Makna Hijrah Bagi Anggota Komunitas Let'S Hijrah Dalam Media Sosial Line. Al-Izzah: Jurnal Hasil-Hasil Penelitian, 14(1), 106. https://doi. org/10.31332/ai.v14i1.1253

Rahmiatie, Atie (2002). Paradigma Baru
Dakwah Islam: Perspektif Komunikasi Massa. Mediator: Jurnal Komunikasi, https://doi.org/10.29313/mediator. v3i1.761

Rakhmani, I. (2016). Mainstreaming Islam in Indonesia. In Mainstreaming Islam in Indonesia. https://doi. org/10.1057/978-1-137-54880-1

Setiawan, E. (2017). Makna Hijrah Pada Mahasiswa Fikom Unisba di Komunitas (followers) Account LINE@ DakwahIslam. Mediator: Jurnal Komunikasi, 10(1), 97-108. https://doi. org/10.29313/mediator.v10i1.2152

Suci Wahyu Fajriani1, Y. S. S. (2019). Hijrah Islami Milenial Berdasarkan Paradigma Berorientasi Identitas. Sosioglobal: Jurnal Pemikiran Dan Penelitian Sosiologi, Vol. 3, No(5).

Sugiyono. (2010). Metode Penelitian Pendidikan Pendekatan Kuantitatif, Kualitatif Alfabeta, dan R\&DNo Title. Alfabeta.

Sunesti, Y., Hasan, N., \& Azca, M. N. (2018). Young Salafi-niqabi and hijrah: Agency and identity negotiation. Indonesian Journal of Islam and Muslim Societies, 8(2), 173-198. https://doi. org/10.18326/ijims.v8i2.173-197

Syahputra, I. (2016). Agama Di Era Media: Kode Religius dalam Industri Televisi Indonesia. ESENSIA: Jurnal IlmuIlmu Ushuluddin, 17(1), 125. https:// doi.org/10.14421/esensia.v17i1.1283

Syahrin, A. A., \& Mustika, B. (2020). Makna Hijrah Bagi Kalangan Remaja Non Santri: Dampak Penggunaan Media Sosial. Jurnal Studi Agama Dan Masyarakat, 16(1), 61-72. https://doi. org/10.23971/jsam.v16i1.1901

Zahara, M. N., Wlidan, D., \& Komariah, S. (2020). Gerakan Hijrah: Pencarian Identitas Untuk Muslim Milenial di Era Digital. Indonesian Journal of Sociology, Education, and Development, 2(1), 58-70.

Dari Hijab Hingga Hijrah. https://historia.id/ kultur/articles/dari-hijab-hingga-hijrah accessed Sunday, August 30th, 03.05 p.m.

Arus Balik Hijrah. https://www.suaraislam. co/arus-balik-hijrah/ accessed Sunday, August 30th, 03.15 p.m. 
Ratri Rizki Kusumalestari. Hijrahtainment: Composing Piety and Profane...

When religion becomes a commodity. https://www.straitstimes.com/opinion/ when-religion-becomes-a-commodity accessed Sunday, August 30, 03.20 p.m.

38 cscholar?hl $=\mathrm{idt}=0 \% 2 \mathrm{C} 5 \& \mathrm{q}=$ tren + berhijrah + di + kalanga ++ mile$\mathrm{n}$ i a $1 \&$ b t $\mathrm{n} \mathrm{G}=\# \mathrm{~d}=\mathrm{g} \mathrm{s}$ qabs\&u=\%23p \%3DTtbLVM961u$\mathrm{MJ}$

Eriyanto. (2012). Analisis Framing: Konstruksi, Ideologi dan Politik Media. LKiS.

Fitri, R. N., \& Jayanti, I. R. (2020). Fenomena Seleb Hijrah: Tendensi Ekslusivisme dan Kemunculan Kelompok Sosial Baru. MUHARRIK: Jurnal Dakwah Dan Sosial, 3(01), 1-17. https://doi. org/10.37680/muharrik.v3i01.222

Gerbner, G. \& L. G. (2007). Living with Television: The Dynamics of the $\mathrm{Cu}$ Itivation Process. https://www. semanticscholar.org/paper/Livingwith-Television-\%3 A-The-Dynamics-of-the-Cu-Gerbner Gross/ d376313 acb 16 fc fa 8160434 ac01a23a8e44cb2dc?p2df

Helen Davis. (2004). The Politics of Representation. In Understanding Stuart Hall. Sage Publications Ltd.

Hjarvard, S. (2008). The mediatization of religion: A theory of the media as agents of religious change. Northern Lights: Film and Media Studies Yearbook, 6(1), 9-26. https://doi. org/10.1386/nl.6.1.9_1

Ispandriamo, L. S. (2016). Agama Dan Media: Pemaknaan Isu Agama Di 'Detiknews.' Millah, XII(2), 595616. https://doi.org/10.20885/millah.volxii.iss 2.art13

Lexy J. Moleong. (2000). Metodologi Penelitian Kualitatif. PT. Remaja Rosdakarya.

Mas'udi. (2017). (Menggagas Prinsip-prinsip Etis dalam Jurnalistik). 211-231. http://journal.stainkudus. ac.id/index.php/komunikasi/article/ download/434/459

McQuail, D. (2010). Teori Komunikasi Massa (Edisi 6). Salemba HUmanika.

Muttaqin, A. (2012). Agama Dalam Representasi Ideologi Media Massa. KOMUNIKA: Jurnal Dakwah Dan Komunikasi, 6(2). https://doi. org/10.24090/komunika.v6i2.349 Osman, N. A. \& M. N. M. (2018).

Islamisation in the Indonesian media spaces new sites for a conservative pushNo Title. LJournal of Religious and Political Practice, Volume 4(Islamisation in Southeast Asia: Religion, Politics and Beyond).

Prasanti, D., \& Indriani, S. S. (2019). Konstruksi Makna Hijrah Bagi Anggota Komunitas Let'S Hijrah Dalam Media Sosial Line. Al-Izzah: Jurnal Hasil-Hasil Penelitian, 14(1), 106. https://doi.org/10.31332/ ai.v14i1.1253

Rahmiatie, Atie (2002). Paradigma Baru Dakwah Islam: Perspektif Komunikasi Massa. Mediator: Jurnal Komunikasi, https://doi.org/10.29313/ mediator.v3i1.761

Rakhmani, I. (2016). Mainstreaming Islam in Indonesia. In Mainstreaming Islam in Indonesia. https://doi. org/10.1057/978-1-137-54880-1

Setiawan, E. (2017). Makna Hijrah Pada Mahasiswa Fikom Unisba di Komunitas (followers) Account LINE@DakwahIslam. Mediator: Jurnal Komunikasi, 10(1), 97-108. https://doi.org/10.29313/mediator. v10i1.2152

Suci Wahyu Fajriani1, Y. S. S. (2019). Hijrah Islami Milenial Berdasarkan Paradigma Berorientasi Identitas. Sosioglobal : Jurnal Pemikiran Dan Penelitian Sosiologi, Vol. 3, No(5).

Sugiyono. (2010). Metode Penelitian Pendidikan Pendekatan Kuantitatif, Kualitatif Alfabeta, dan R\&DNo Title. Alfabeta. 
Sunesti, Y., Hasan, N., \& Azca, M. N. (2018). Young Salafi-niqabi and hijrah: Agency and identity negotiation. Indonesian Journal of Islam and Muslim Societies, 8(2), 173198. https://doi.org/10.18326/ijims. v8i2.173-197

Syahputra, I. (2016). Agama Di Era Media: Kode Religius dalam Industri Televisi Indonesia. ESENSIA: Jurnal Ilmu-Ilmu Ushuluddin, 17(1), 125. https://doi.org/10.14421/esensia.v17i1.1283

Syahrin, A. A., \& Mustika, B. (2020). Makna Hijrah Bagi Kalangan Remaja Non Santri: Dampak Penggunaan Media Sosial. Jurnal Studi Agama Dan Masyarakat, 16(1), 61-72. https://doi.org/10.23971/ jsam.v16i1.1901
Zahara, M. N., Wlidan, D., \& Komariah, S. (2020). Gerakan Hijrah : Pencarian Identitas Untuk Muslim Milenial di Era Digital. Indonesian Journal of Sociology, Education, and Development, 2(1), 58-70.

Dari Hijab Hingga Hijrah. https://historia. $\mathrm{id} /$ kultur/articles/dari-hijab-hingga-hijrah accessed Sunday, August 30th, 03.05 p.m.

Arus Balik Hijrah. https://www.suaraislam.co/arus-balik-hijrah/ accessed Sunday, August 30th, 03.15 p.m.

When religion becomes a commodity. https://www.straitstimes.com/opinion/when-religion-becomes-a-commodity accessed Sunday, August 30 , 